\title{
Assessment of Coating Zirconium Implant Material with Nanoparticles of Faujasite
}

\author{
Ahmed Ali Mohammed (1), Thekra Ismael Hamad ${ }^{(2)}$ \\ https://doi.org/10.26477/jbcd.v33i4.3016
}

\begin{abstract}
Aim: To evaluate the wettability and microhardness of Zirconium $\left(\mathrm{ZrO}_{2}\right)$ dental material when coated with different concentrations of Faujasite.

Materials and methods: 30 circular disks produced from $\mathrm{ZrO}_{2}$, then each group is classified into 10 control groups, 10 coated groups with 3\% Faujasite, and 10 coated groups with 7\% faujasite by electro-spun tool to study variable properties in hardness and water contact angle of implant materials.

Results: This study stated the high hardness in $7 \%$ of faujasite concentration for $\mathrm{ZrO}_{2}$, in addition, the contact angle decreased gradually until reach $0^{\circ}$ in $7 \%$ concentration of faujasite with $\mathrm{ZrO}_{2}$

Conclusion: Water contact angle (WCA) declined till disappeared in (7\% wt.) of faujasite coated with the $\mathrm{ZrO}_{2}$ group, also in the same group the microhardness became high compared with other groups due to alteration in surface morphology of substrate, and properties of coated material.

Keywords: electrospinning, microhardness, wettability, circular disk, Polyvinylpyrrolidone (PVP), water contact angle. (Received: 28/9/2021, Accepted: 30/10/2021)
\end{abstract}

\section{INTRODUCTION}

Titanium was used as a dental material for several decades and considered as standardization of dental implants but because of disadvantages such as galvanic corrosion and cellular sensitivity associated with the saliva of humans ${ }^{(1)}$, it was an alternative with ceramic dental material such as zirconia(zircon strong transition metal, grey-white, and lustrous named Zirconium), it was the oxide form of Zircon ${ }^{(2)}$.

${ }^{2}$ In 1824 Jones Jakob Berzelius was the first to produce zirconium in the form of impure. In dentistry, it was utilized to fabricate esthetic orthodontic brackets, crown/bridge, endodontic posts, implant abutments for rehabilitation of partial and complete arches, and restorations. Faujasite was classified into $\mathrm{Y}$ had a Si/Al ratio of more than 1.5, and $\mathrm{X}$ had a Si/Al from (1_1.5). Zeolitic materials were characterized mainly by their ion exchange and adsorption capacities. In addition, they can be produced in the laboratory using low-, cost raw materials. These materials have been widely used as adsorbents, molecular sieves, and ion exchangers in the treatment of wastewater, air purifiers, catalysts, and catalyst support ${ }^{(3)}$. The hardest of ceramic was

(1) PhD student, Al-Diwaniya Directorate, Ministry of Health Baghdad, Iraq.

(2) Professor. Department of Prosthodontic, college of dentistry,

University of Baghdad, Baghdad, Iraq

Corresponding email, drtooth80@ hotmail.com a Zirconia. It was widely produced in a monolithic phase for many clinical usages, was known as yttria-stabilized tetragonal zirconia polycrystal (YTZP). Different types of Y-TZP found can be based on heat treatment, sintering, dopants, and additives (4). Absence of toxicity and good mechanical properties of Y-TZP was forced to choose it in dental usage, though it had one problem about matching it with natural teeth to improve esthetic ${ }^{(5)}$. Electrospinning was one way to produce filaments (ultrafine fiber) from many types of materials like composite, polymer, and ceramic. The machine was composed of three parts, conductive collector, syringe with metallic needle, and voltage power supply. This process was divided into various techniques such as bubble electrospinning, Siroelectrospinning, vibration electrospinning, and magneto-electrospinning ${ }^{(6)}$. Various devices were utilized to analyze surface texture and surface properties such as water contact angle (WCA) and microhardness by the X-Ray diffraction and Energy diffraction spectroscopy ${ }^{(7)}$.

\section{MATERIALS AND METHODS}


Partially sintered zirconia from VITA was supplied in block disc with a dimension of $98.4 \mathrm{~mm}$ in diameter and $12 \mathrm{~mm}$ in height, the white shade (A1), was cut into small circular discs $(10 \mathrm{~mm}$ diameter and $1 \mathrm{~mm}$ thickness) as shown in figure (1) the substrates prepared with exo-cad dental CAD Software. To prepare zirconia samples, fractional sintered zirconia block disc was cut according to the selected measurements utilizing a dental computerized three-axis milling system, computeraided design /computer-aided manufacturing (CAD/CAM) imes-icore, Germany), substrates sintered in sintering heater of imes-icore up to $1650^{\circ} \mathrm{C}$, according to manufacture instruction. Then, substrates were cleaned ultrasonically in ethanol for half an hour and then put aside in the air before coating ${ }^{(8)}$. polyvinylpyrrolidone (PVP) (MW: 40,000) was produced by alpha chemical (made in India), PVP, and distilled water was considered as a solvent for the faujasite manufactured by China with a particle size of about 286.7 as shown in the figure (2) and measurements of parameters device mentioned in table (1). The sample of Zirconia coated with Faujasite by using the electrospun technique is shown below

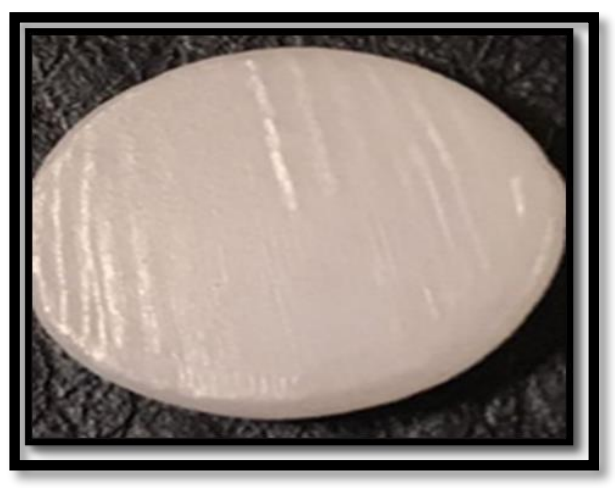

Figure 1 Zirconium disk

By using an electrospinning machine (made in the USA), filaments was formed after mixing $40 \%$ wt. of PVP with concertation of Faujasite $(3 \% \& 7 \%)$, and addition D.W. to become the mixture solution 5 $\mathrm{gm}$ for each percentage, the parameters of the machine were $20 \mathrm{~K} . \mathrm{V}$. of the voltage supply, flow rate $(1.5 \mathrm{ml} / \mathrm{h}$.), and the distance $(13 \mathrm{Cm})$ between detector with samples and head of needle syringe found in the electrospun machine after the filaments were formed, all samples were kept in room temperature to evaporate the solvent ${ }^{(9)}$.

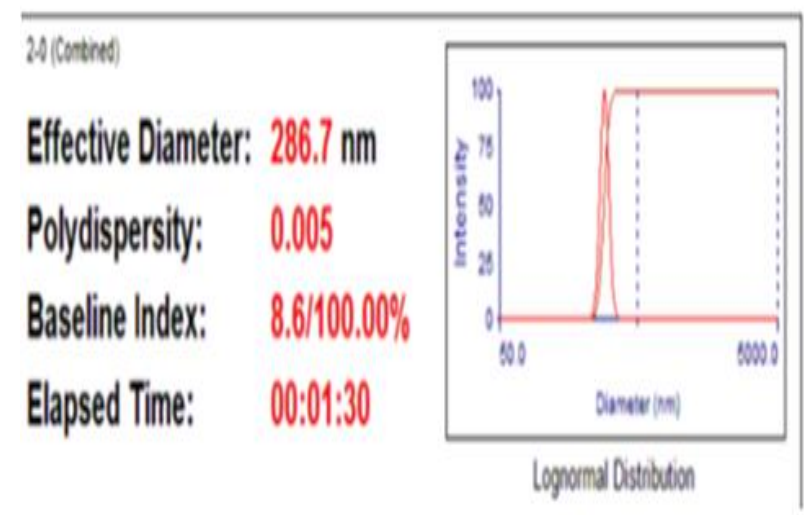

Figure 2 Particle Size Analyzer of Faujasite

Table 1 Measurement Parameter of Particle Size Analyzer Device

\begin{tabular}{|c|c|c|c|}
\hline temperature & $=25.0$ deg. $C$ & $\begin{array}{l}\text { Runs } \\
\text { completed }\end{array}$ & $=3$ \\
\hline liquid & = water & Burn duration & $=00: 00: 30$ \\
\hline viscosity & $=0.890 \mathrm{cp}$ & $\begin{array}{l}\text { Total elapsed } \\
\text { time }\end{array}$ & $=00: 01: 30$ \\
\hline $\begin{array}{l}\text { Ref. index } \\
\text { fluid } \\
\text { angle }\end{array}$ & $\begin{array}{l}=1.330 \\
90.00\end{array}$ & $\begin{array}{l}\text { Average } \\
\text { count rate } \\
\text { Ref. index real }\end{array}$ & $\begin{array}{l}=450.1 \\
\text { Keps } \\
=1.590\end{array}$ \\
\hline wavelength & 660.00 & $\begin{array}{l}\text { Ref. index } \\
\text { image }\end{array}$ & $=0.000$ \\
\hline baseline & $\begin{array}{l}\text { Auto (slope } \\
\text { analysis) }\end{array}$ & $\begin{array}{ll}\text { Dust } & \text { filter } \\
\text { setting } & \end{array}$ & $=30.00$ \\
\hline
\end{tabular}

\section{RESULTS}

\section{Characterization}

Nanofibers were characterized by the energy diffraction spectroscopy (EDS) and x-ray diffraction (XRD) in order to evaluate water contact angle and microhardness for various percentage coating of faujasite and compared with uncoating group.

\section{The energy diffraction spectroscopy (EDS)}

It was a method to determine element composition material which formed samples and then analyzed by forming peaks for each ingredient and examination by energy dispersive $\mathrm{x}$-ray spectroscopy (made in Netherland) 


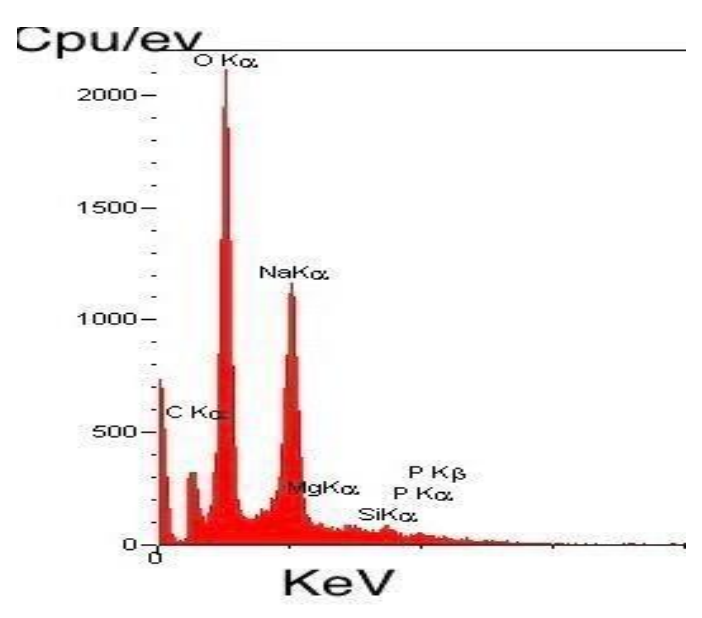

Figure 3 EDX of Uncoated Zirconia

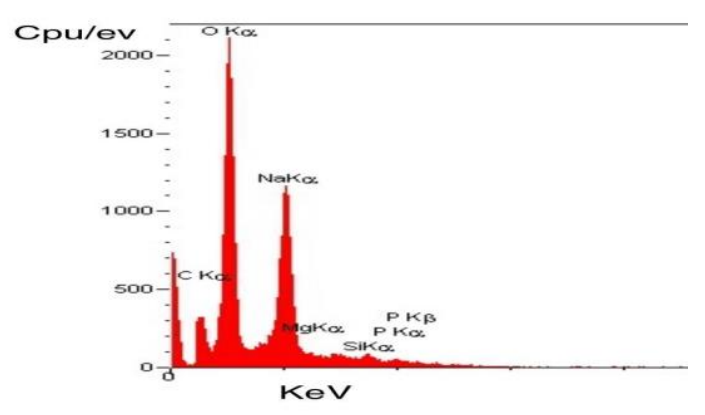

Figure 4 EDX of Zirconia coated 3\% Faujasite

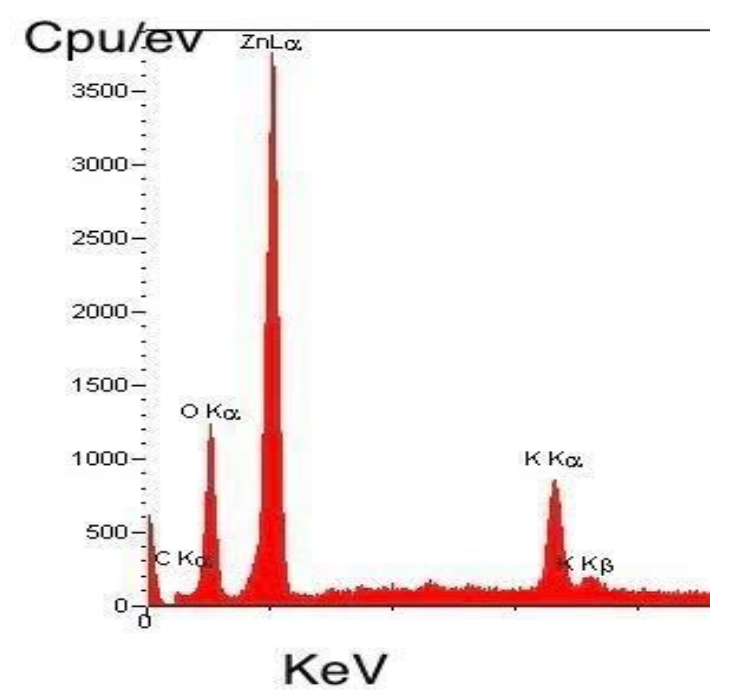

Figure 5 EDX of Zirconia Coated $7 \%$ Faujasite

\section{X-ray diffraction (XRD)}

An automated X-ray Diffractometer was employed for Phase analysis by using $\mathrm{Cu}-\mathrm{K} \alpha$ radiation $\left(\lambda=1.5406 \mathrm{~A}^{\circ}\right)$, XRD-6000, SHIMADZU (Japan) The operation was done at $30 \mathrm{~mA}$ and $40 \mathrm{kV}$. Ambient laboratory temperature using 10s/angular step ( 1 angular step $\left.=0.02^{\circ}\right)$ was used for taken diffraction patterns, depending on the joint committee on powder diffraction standards (JCPDS) of the international center for the diffraction data the peak indexing was carried out.

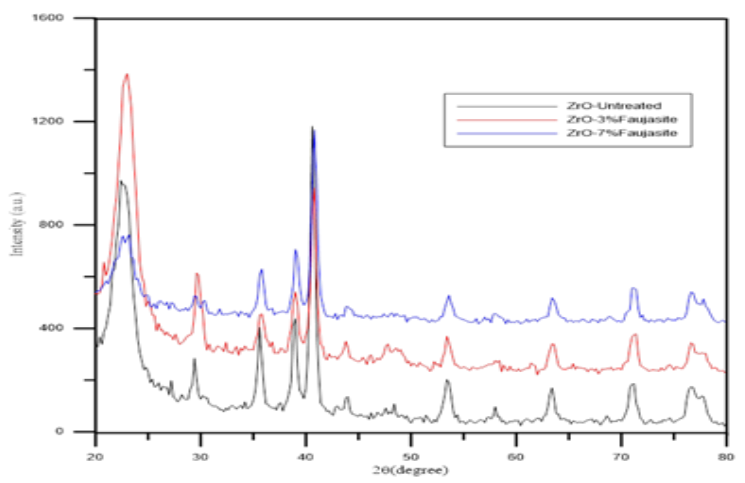

Figure 6 XRD of Uncoated, coated $3 \%$ Faujasite(F) and coated $7 \%$ Faujasite (F) Zirconia, Groups

\section{Wettability Analysis}

In the Department of Chemical Engineering / University of Technology, Iraq. The measurements of wettability were done by goniometer CAM 110, made in Germany, to survey the effect of different percentages of faujasite coating with $\mathrm{ZrO}_{2}$ and evaluate wettability phenomena on selected disks 30 seconds was needed to capture an image after applying a drop of liquid on an intended surface, the procedure occurred at an ambient temperature.

\section{Microhardness test}

Digital Vickers micro-hardness tester Buehler Micrometer 5103, USA, was used to record the micro-hardness of the $\mathrm{ZrO}_{2}$ disks coated by faujasite with $3 \%$ and $7 \%$, and uncoated disks according to (ASTM E92-82, 1997), for 5 seconds $9.8 \mathrm{~g}$ load was applied to the surface of the disk by using Vickers indenter that joins optical microscopy. An average of 3 different readings was measured from the ten $\mathrm{ZrO}_{2}$ specimens for each selected concentration to compare between the control and coating groups.

The interpretations EDX for each percentage of faujasite $(3 \%$ and $7 \%)$ in respectively were shown 
in fig (4), (5, utilized in the coating of Zirconia and compared it with the control group as seen in fig (3). Also, tables (2), (3), and (4) showed the quantities results for all groups control, coated 3\%, and coated $7 \%$ of Faujasite in respectively.

Table 2 Quantitive Results of Uncoated Group

\begin{tabular}{rrrlllll}
\hline Elt & Line & \multicolumn{1}{c}{ Int } & K & Kr & W\% & \multicolumn{1}{l}{ A\% } & ZAF \\
\hline $\mathrm{C}$ & $\mathrm{Ka}$ & 73.5 & 0.1726 & 0.0734 & 22.25 & 29.34 & 0.3298 \\
$\mathrm{O}$ & $\mathrm{Ka}$ & 512.1 & 0.5986 & 0.2545 & 57.49 & 56.93 & 0.4426 \\
$\mathrm{Na}$ & $\mathrm{Ka}$ & 434.1 & 0.1938 & 0.0824 & 17.86 & 12.30 & 0.4615 \\
$\mathrm{Mg}$ & $\mathrm{Ka}$ & 30.7 & 0.0128 & 0.0054 & 1.11 & 0.72 & 0.4908 \\
$\mathrm{Si}$ & $\mathrm{Ka}$ & 28.5 & 0.0122 & 0.0052 & 0.73 & 0.41 & 0.7111 \\
$\mathrm{P}$ & $\mathrm{Ka}$ & 20.5 & 0.0100 & 0.0042 & 0.56 & 0.29 & 0.7525 \\
& & & 1.0000 & 0.4251 & 100.00 & 100.00 & \\
\hline
\end{tabular}

Table 3 Quantitive Results of Zirconia Coated 3\% Faujasite

\begin{tabular}{llllllll}
\hline Elt & Line & Int & K & Kr & W\% & A\% & ZAF \\
\hline C & Ka & 41.5 & 0.1049 & 0.0388 & 15.87 & 21.50 & 0.2442 \\
$\mathbf{O}$ & Ka & 636.0 & 0.6807 & 0.2515 & 62.48 & 63.56 & 0.4025 \\
$\mathbf{N a}$ & Ka & 483.6 & 0.1700 & 0.0628 & 18.87 & 13.36 & 0.3328 \\
$\mathbf{A l}$ & Ka & 38.2 & 0.0115 & 0.0042 & 0.89 & 0.54 & 0.4749 \\
$\mathbf{S i}$ & Ka & 47.4 & 0.0145 & 0.0054 & 0.88 & 0.51 & 0.6067 \\
$\mathbf{P}$ & Ka & 54.3 & 0.0184 & 0.0068 & 1.00 & 0.53 & 0.6776 \\
& & & 1.0000 & 0.3694 & 100.00 & 100.00 & \\
\hline
\end{tabular}

Table 4 Quantitive Results of Zirconia Coated 7\% Faujasite

\begin{tabular}{cccccccc}
\hline ELT & LINE & NIT & K & KR & W\% & A\% & ZAF \\
\hline C & KA & 5.2 & 0.0114 & 0.0066 & 3.56 & 7.10 & 0.1850 \\
0 & KA & 314.4 & 0.2937 & 0.1696 & 49.33 & 73.78 & 0.3438 \\
K & KA & 285.1 & 0.1147 & 0.0662 & 7.61 & 4.66 & 0.8707 \\
Zn & KA & 351.8 & 0.5801 & 0.3350 & 39.50 & 14.46 & 0.8480 \\
& & & & & & & \\
& & & 1.0000 & 0.5774 & 100.00 & 100.00 & \\
\hline
\end{tabular}

Phase analysis was applied to the samples before coating surface structuring, and after coating technique for 3 and $7 \%$ concentration of Faujasite besides the control disks as seen in fig. (6) and basic data in the table (5) showed the three strongest peaks in each group which interpreted amount of changing occurred by the effect of treatment with faujasite that included peak number, 2 theta degrees, amount of diffraction, intensity, and full width at a high maximum of XRD profile
Table 5 Basic Data of XRD for Study Groups

\begin{tabular}{|c|c|c|c|c|}
\hline \multicolumn{5}{|c|}{ Uncoated ZrO2 } \\
\hline $\begin{array}{l}\text { Peaks } \\
\text { no. }\end{array}$ & $\begin{array}{l}2 \text { Theta } \\
\text { (degree) }\end{array}$ & $\begin{array}{l}\text { Diffraction } \\
\text { (Angstrom) }\end{array}$ & Intensity(I/I1) & FWHM \\
\hline 3 & 30.1423 & 2.96248 & 100 & 0.5726 \\
\hline 8 & 50.1979 & 1.81596 & 60 & 0.6307 \\
\hline 5 & 34.7594 & 2.57882 & 29 & 0.3893 \\
\hline \multicolumn{5}{|c|}{ 3\% Faujasite coated ZrO2 } \\
\hline 2 & 30.2361 & 2.95351 & 100 & 0.6756 \\
\hline 5 & 50.3643 & 1.81035 & 54 & 0.6924 \\
\hline 3 & 34.9005 & 2.56871 & 27 & 0.525 \\
\hline \multicolumn{5}{|c|}{ 7\% faujasite coated ZrO2 } \\
\hline 2 & 29.927 & 2.9833 & 100 & 0.8327 \\
\hline 7 & 50.0502 & 1.82097 & 70 & 0.9082 \\
\hline 8 & 59.2329 & 1.55871 & 43 & 1.0167 \\
\hline
\end{tabular}

The mean water contact angle in $\mathrm{ZrO}_{2}$ with $7 \%$ faujasite was Zero degree, and for the $\mathrm{ZrO}_{2}$ with $3 \%$ faujasite was $21.46^{\circ}$ but for control, $\mathrm{ZrO}_{2}$ was $77.72^{\circ}$ and descriptive statistics of water contact angle test of the 3 groups were summarized in table (6). The table shows the lowest water contact in group $\mathrm{ZrO}_{2}$ $7 \%$ Faujasite $(\mathrm{F})(0)^{\circ}$ and the highest value of water contact in the control group of $\mathrm{ZrO}_{2}\left(78.65^{\circ}\right)$.

Table 6 descriptive statistic WCA for Zirconia groups

\begin{tabular}{lcccll} 
Groups & No. & mean & Std & Min & Max \\
\hline $\mathrm{ZrO}_{2} \mathrm{C}$ & 10 & 77.72 & 0.579 & 76.65 & 78.65 \\
$\mathrm{ZrO}_{2}$ & 10 & 21.461 & 1.049 & 20.121 & 22.876 \\
$3 \% \mathrm{~F}$ & & & & & \\
$\mathrm{ZrO}_{2}$ & 10 & zero & zero & zero & zero \\
$7 \% \mathrm{~F}$ & & & & & \\
\hline
\end{tabular}

Statistically, the F-test of the one-way ANOVA test showed a non-significance difference in the water contact angle among the 3 groups, because of $\mathrm{P}>.05$ at three degrees of freedom, as shown in table (7).

Table 7 One-way ANOVA Test of WCA

\begin{tabular}{cccccc}
\hline $\begin{array}{c}\text { Source of } \\
\text { variance }\end{array}$ & DF & SS & MS & F & P \\
\hline $\begin{array}{c}\text { Between } \\
\text { Groups }\end{array}$ & 1 & 1586 & 1586 & 1.969 & 0.233 \\
$\begin{array}{l}\text { Within } \\
\text { groups } \\
\text { total }\end{array}$ & 4 & 3222.3 & 805.575 & & N.S \\
\hline
\end{tabular}


Three readings were obtained from each of the thirty specimens (ten discs for each group) by using the Vickers microhardness tester by applying $9.8 \mathrm{~g}$ load for 5-second descriptive statistics for microhardness was seen in the table (8). The table shows the lowest mean value for group Control (C) of $\mathrm{ZrO}_{2}$ was $1275.38 \mathrm{H} . \mathrm{V}$. and $1683.65 \mathrm{H} . \mathrm{V}$. the highest mean was in group $\mathrm{ZrO}_{2} 7$ \% Faujasite (F).

Table 8 Descriptive statistic of Vickers microhardness test for Zirconia groups

\begin{tabular}{cccccc}
\hline Groups & No. & mean & Std & $\min$ & Max \\
\hline ZrO2 C & 10 & 1275.38 & 43.446 & 1190 & 1349 \\
$\mathrm{ZrO} 23 \% \mathrm{~F}$ & 10 & 1646.4 & 87.398 & 1521 & 1763 \\
$\mathrm{ZrO} 27 \% \mathrm{~F}$ & 10 & 1683.65 & 69.824 & 1587 & 1790 \\
\hline
\end{tabular}

ANOVA test seen in table (9) revealed that there was a highly significant difference among the groups $\mathrm{P} \leq .01$ at 3 degrees of freedom.

Table 9 one-way ANOVA Test for Vickers Microhardness of Zirconia Groups

\begin{tabular}{cccccc}
\hline $\begin{array}{c}\text { Source of } \\
\text { Variation }\end{array}$ & DF & SS & MS & F & P \\
\hline $\begin{array}{c}\text { Between } \\
\text { Groups }\end{array}$ & 2 & 6.290 & 0.645 & 14.106 & 0.000 \\
Residual & 27 & 62.216 & 4.48 & & H.S \\
Total & 29 & 2.507 & & & \\
\hline
\end{tabular}

\section{DISCUSSION}

In XRD analysis between study groups of $\mathrm{ZrO}_{2}$ as seen in fig. (7) and table (5) especially at the intensity 100 (I/I1) showed a high difference in the full width at a high maximum of XRD profile (FWHM) which was responsible to describe surface and various material properties like plastic deformation, mechanical properties, and changed in microhardness, many surveys stated FWHM was an accurate signal of the surface work hardening compared with another microhardness testing. In this study, the results showed the (FWHM) at some intensity increased from 0.57 degrees in control groups and become in study groups coating $3 \% \mathrm{~F}$ 0.67 degree till reached to 0.83 degrees with a group of $7 \% \mathrm{~F}$ coated of $\mathrm{ZrO}_{2}{ }^{(10)}$.
In table (4) compared with table (2), and (3) the EDX interpreted the present zinc clearly with study groups coated with 7\% faujasite which was responsible to modify the mechanical and wettability properties, the addition of zinc to the Ti$6 \mathrm{Al}-4 \mathrm{~V}$ result in low the modulus of elasticity and enhancement of microhardness, also Zinc (Zn) particles cause improvement in hydrophilicity and biocompatibility through cell proliferation and adhesion (11). Due to the foundation of oxygen, sodium, silicon, and aluminum in selected samples, there appeared in their low XPS resolution spectra. Faujasite has interpreted the crystallinity via EDS, and FTIR analysis ${ }^{(12)}$.

WCA was decreased gradually with increased concentration of faujasite for dental implant materials until reached $\mathrm{WCA}=0^{\circ}$ with coating 7\% concentration of faujasite to $\mathrm{ZrO}_{2}$, interpreted increasing hydrophilicity of materials when coated with Faujasite to improve dental implant properties, was significant with water absorption capability, it was a critical parameter to determine the liquid uptake from the media, Therefore, it can be considered as a significant indicator to evaluate the suitability of biomaterial for tissue engineering usages (13) The $\theta$ angle for each scaffold was observed when a drop of water placed on the sample, for PLGA (poly lactic-co-glycolic acid/scaffold), $\theta=123.8^{\circ} \pm 5^{\circ}$, It shows that the structure of pure polymeric scaffold was hydrophobic for PLGA/zeolite 3 (wt.\%), $\theta$ was declined to $101.83^{\circ} \pm 6^{\circ}$, while nano-scaffold was stayed hydrophobic. Water contact angles for PLGA/zeolite 7 (wt.\%) and PLGA/zeolite 10 (wt.\%) were $94.64^{\circ} \pm 6^{\circ}$ and $82.08^{\circ} \pm 4^{\circ}$, in sequence. This showed that adding more zeolite to PLGA made it more hydrophilic. These results observed that nanoparticle zeolite powder utilized in the composite had a high tendency to water wettability ${ }^{(14)}$.

In Zirconia groups showed enhancement in microhardness values with coating material due to increase ingrain particle size and surface roughness caused bonding between coating materials and substrate of zirconia ${ }^{(15)}$. Other investigations may be demonstrated this variation by examination and study increase the microhardness associated with magnifying grain size and diminishing surface roughness due to the load applied diminished upon micro-crack adjacent to the penetration area of diamond tool ${ }^{(16)}$. 


\section{CONCLUSION}

This study clarified the microhardness and water contact angle (WCA) improved in $\mathrm{ZrO}_{2}$ groups by enhancement the concentration of nanoparticles of faujasite to develop dental implant material and restriction of implant failure in the future with advanced coated techniques.

\section{REFERENCES}

1. Safi IN, Hussein BMA, Al Shammari AM, et al. Implementation and characterization of coating pure titanium dental implant with sintered $\beta$-TCP by using Nd: YAG laser. Saudi Dent J. 2019; 31: 242-50.

2. Kim KT, Eo MY, Nguyen TTH, et al. General review of titanium toxicity. Int J Implant Dent. 2019 ; 5: 10 .

3. Burakov AE, Galunin E V., Burakova I V., et al. Adsorption of heavy metals on conventional and nanostructured materials for wastewater treatment purposes: A review, Ecotoxicol Environ Saf. Academic Press; 2018; 148: .702-712.

4. Zhang Y, Lawn BR. Novel Zirconia Materials in Dentistry. J Dent Res. 2018 ;97: 140-147

5. Pieger S, Salman A, Bidra AS. Clinical outcomes of lithium disilicate single crowns and partial fixed dental prostheses: A systematic review, Mosby Inc.; 2014; 112: p. 22-30.

6. Shao $\mathrm{H}$, Fang $\mathrm{J}$, Wang $\mathrm{H}$, et al. Effect of electrospinning parameters and polymer concentrations on mechanical-to-electrical energy conversion of randomly-oriented electrospun poly(vinylidene fluoride) nanofiber mats. RSC Adv. 2015; 5: 14345-50.

7. Rusli MSIC, Hassan MI, Sultana N, et al. Characterization of PCL/zeolite electrospun membrane for the removal of silver in drinking water. J Teknol. 2017; 79:89-95.
8. Safi IN, Hussein BMA, Al-Shammari AM. Testing and characterization of sintered $\beta$-tricalcium phosphate coat upon zirconia dental implant using Nd: YAG laser. J Laser Appl. 2019;31:032002-13.

9. Anis SF, Hashaikeh R. Electrospun zeolite-Y fibers: Fabrication and morphology analysis. Microporous Mesoporous Mater. 2016; 1:78-86.

10. Vashista M, Paul S. Correlation between full width at half maximum (FWHM) of XRD peak with residual stress on ground surfaces. Philos Mag. 2012; 92: 4194204.

11. Zhu C, Lv Y, Qian C, et al. Microstructures, mechanical, and biological properties of a novel Ti-6V$4 \mathrm{~V} /$ zinc surface nanocomposite prepared by friction stir processing. Int J Nanomedicine 2018;13:1881-98.

12. Zahmakiran M, Özkar S. Zeolite confined nanostructured dinuclear ruthenium clusters: Preparation, characterization and catalytic properties in the aerobic oxidation of alcohols under mild conditions. J Mater Chem. 2009; $19: 7112-8$.

13. Prasopdee T, Sinthuvanich C, Chollakup R, et al. The albumin/starch scaffold and its biocompatibility with living cells. Mater Today Commun. 2021; 2 7: 102164.

14. Davarpan R, Rafienia M, Salehi Rozve H, et al. Fabrication and characterization of electrospun poly lactic-co-glycolic acid/zeolite nanocomposite scaffolds using bone tissue engineering. J Bioact Compat Polym. 2018; 33:63-78.

15. Lin SC, Lin WC, Hu TC, et al. Evaluation of the bonding strength between various dental zirconia models and human teeth for dental posts through in vitro aging tests. Coatings 2021; Vol 11, Page 1017.

16. Song N, Wang Z, Xing Y, et al. Evaluation of phase transformation and mechanical properties of metastable Yttria-Stabilized Zirconia by nanoindentation. Materials (Basel). 2019; 12: 1677.

\footnotetext{
الخلاصة

الهـف:هو تقييم قابلية الابتلال و الصلادة لاقر اص مادة الزركنيوم دايوكسايد المستعطله في زر اعة الاسنان عند طلائها بتر اكيز مختلفة من مادة الفوجاسيت.

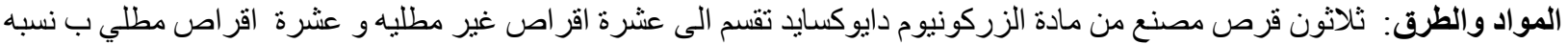

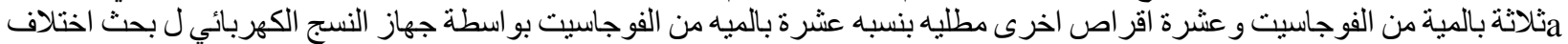

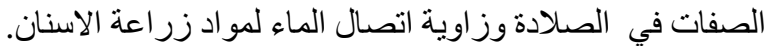

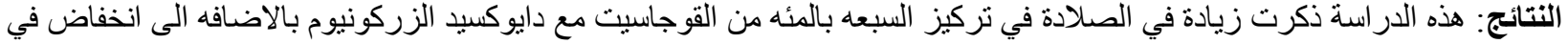

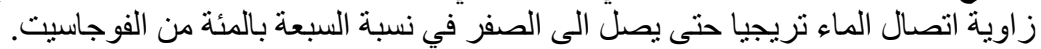

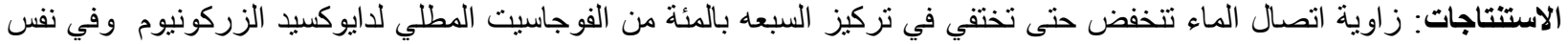
التركيز خاصية الصلادة تصبح كبيرة مقارنة بالمجاميع الاخرى نتيجة تغير الثكل الخارجي للمادة المر اد طلائها وخو اصلئ مادة الطلاء.
}

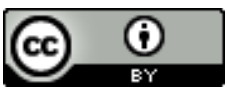

Articles Published by Journal of Baghdad College of Dentistry is licensed under a Creative Commons Attribution 4.0 International License. 